\title{
The effects of phenoxy herbicide MCPA on non-target vegetation in spring wheat (Triticum aestivum L.) culture
}

\author{
Jūratė Žaltauskaitė \\ Giedrè Kišonaitė \\ Vytautas Magnus University, \\ Vileikos str. 8, \\ LT-44404 Kaunas, Lithuania
}

The presentation was made at the 8th international conference "The Vital Nature Sign" on 15-17 May, 2014

The study examined the non-target effects of phenoxy herbicide MCPA (4-chloro-2-methyl-phenoxy acid) on the morphological and physiological characteristics of spring wheat (Triticum aestivum L.) under field conditions. The experiment was conducted in 4 mesocoms plots ( 0.1 a) from May to August 2012. The plants were sprayed directly with herbicide spray solutions equivalent of recommended field application rate. The measured endpoints were as follows: height of the shoots, length of the roots, dry biomass, concentrations of chlorophyll $a, b$, carotenoids, malondialdehyde (MDA). The yield of wheat and residues of MCPA in wheat tissues and soil were also estimated. It was observed that herbicide slightly reduced spring wheat stem height (by $9 \%, p<0.05)$, increased root length ( $p>0.05)$. Dry weight of spring wheat stems and roots decreased by $14 \%(\mathrm{p}<0.05)$ and $17 \%(\mathrm{p}>0.05)$, respectively. The herbicide did not evoke significant effect on the content of photosynthetic pigments and MDA in plant tissues. MCPA herbicide residues were observed only in soil and stems of spring wheat and were $0.97 \mu \mathrm{g} / \mathrm{kg}$ and $0.047 \mathrm{mg} /$ $\mathrm{kg}$, respectively.

Key words: herbicides, non-target plant, oxidative stress, phytotoxicity, Triticum aestivum

\section{INTRODUCTION}

Phytohormones (auxins, gibberellins, cytokinins, ethylene and abscisic acid) are fundamentals for the plant growth and development. Auxins regulate and stimulate cell elongation and division (Kende, Zeevaart, 1997). However, high tissue auxins concentration leads to adverse effects in plants resulting in plant tissue decay and plant death. Due to this, synthetic auxins are widely used in agriculture as herbicides.

\footnotetext{
* Corresponding author. E-mail: j.zaltauskaite@gmf.vdu.lt
}

Since their discovery in 1950s auxin herbicides are among the most widely used herbicides. Phenoxy (auxin) herbicide MCPA (4-chloro-2-methyl-phenoxy acid) has the same metabolism as the natural auxin growth hormone indole-3-acetic acid. The application of these herbicides leads to the imbalance of plant hormones and stimulation of the biosynthesis of plant growth hormones ethylene and abscisic acid (Grossmann, 2000; Hansen, Grossmann, 2000).

The phytotoxic effect of phenoxy herbicides is basically caused by high concentrations of 
biosynthetized abscisic acid leading to stomata closure and inhibition of transpiration and $\mathrm{CO}_{2}$ assimilation (Fedtke, Duke, 2005). These effects are followed by foliar senescence with chloroplast damage and by the destruction of membrane and vascular system integrity and plant death (Grossman, 2000). The mode of action of MCPA is similar to that of other widely used phenoxy acids such as $2,4-\mathrm{D}, 2,4-\mathrm{DB}, 2,4,5-\mathrm{T}$ and others.

MCPA is slightly persistent in soils with a half-life approximately 6 weeks (Goring et al., 1975). However, under certain circumstances it may persist for longer periods. Degradation is mainly due to microbial activity, photodegradation and hydrolysis. MCPA is mobile in most soil types and it has a potential to contaminate surface waters (Comoretto et al., 2007) and groundwater (Caux et al., 1995).

Despite of the wide use of MCPA, the toxicity evaluation principally was conducted only under laboratory conditions and field studies are lacking. Field studies have shown that nontarget vegetation is at risk of accidental herbicide exposure, by direct overspray or indirectly by spray drift from aerial or ground applications (Mars et al. 1989; de Snoo, van der Poll, 1999). As it has been shown that phenoxy herbicides may adversely affect the seed germination and early shoot or root growth (Fargašová, 1994; Grabińska-Sota et al., 2003), it suggests that MCPA may affect the growth of non-target plants in all life stages and yield. However, the studies analysing MCPA effects on non-target vegetation growth and yield under field conditions are lacking. The main aim of the study was to evaluate the phenoxy herbicide MCPA biochemical, physiological and morphological effects on spring wheat (T. aestivum) under field conditions.

\section{MATERIALS AND METHODS}

The field study was conducted in wheat (Triticum aestivum L.) culture from May to August, 2012. The experiment was conducted in 4 mesocoms plots $(0.1 \mathrm{a})$. The plants ( 4 weeks of age) in two mesocosm plots were sprayed directly with MCPA (4-chloro-2-methyl-phenoxy acid) herbicide sprays solutions equivalent of recommended field application rate $(1.5 \mathrm{l} / \mathrm{ha})$. The other two mesocosm plots were as control plots.

Biochemical, physiological and morphological effects measurements were conducted after 2 months of the exposure. The soil samples were analysed for herbicide residue. Estimated endpoints were as follows: root and shoot growth, biomass (fresh and dry weight), content of photosynthetic pigments (chlorophyll a, $\mathrm{b}$ and carotenoids), and content of malondialdehyde. The yield of spring wheat (T. aestivum) was evaluated as spike length and weight, grain amount in spike, fresh and dry weight of grains and hulls. The MCPA residues in wheat grains, above ground wheat tissues and in soil were measured.

For dry weight assessment, the plants were dried at $60{ }^{\circ} \mathrm{C}$ for $48-72 \mathrm{~h}$ up to constant weight. The content of photosynthetic pigments (chlorophyll $a, b$ and carotenoids) was measured spectrophotometrically in 100\% acetone extract plant tissue (Von Wettstein, 1957). Concentration of malondialdehyde (MDA), the by-product of lipid peroxidation, was used as biomarker of membrane oxidative damage. MDA content was determined by reaction with thiobarbituric acid (Buege, Aust, 1978). MCPA herbicide residues in wheat (shoots and grains) and soil were analysed by HPLC according to the method described by Hu et al. (2012).

A one-way analysis of variance (ANOVA) was used to assess the herbicide effect on estimated endpoints. Significant differences between control and samples, treated with herbicide, were determined by the Mann Whitney U-test and were considered to be significant at $\mathrm{p}<0.05$. The statistical analysis was carried out using Statistica software.

\section{RESULTS AND DISCUSSION}

During the field study it was observed that MCPA application slightly, however, statistically significantly $(\mathrm{p}<0.05)$ reduced the height of spring wheat (Triticum aestivum) (Fig. 1). After the MCPA application the shoots were 


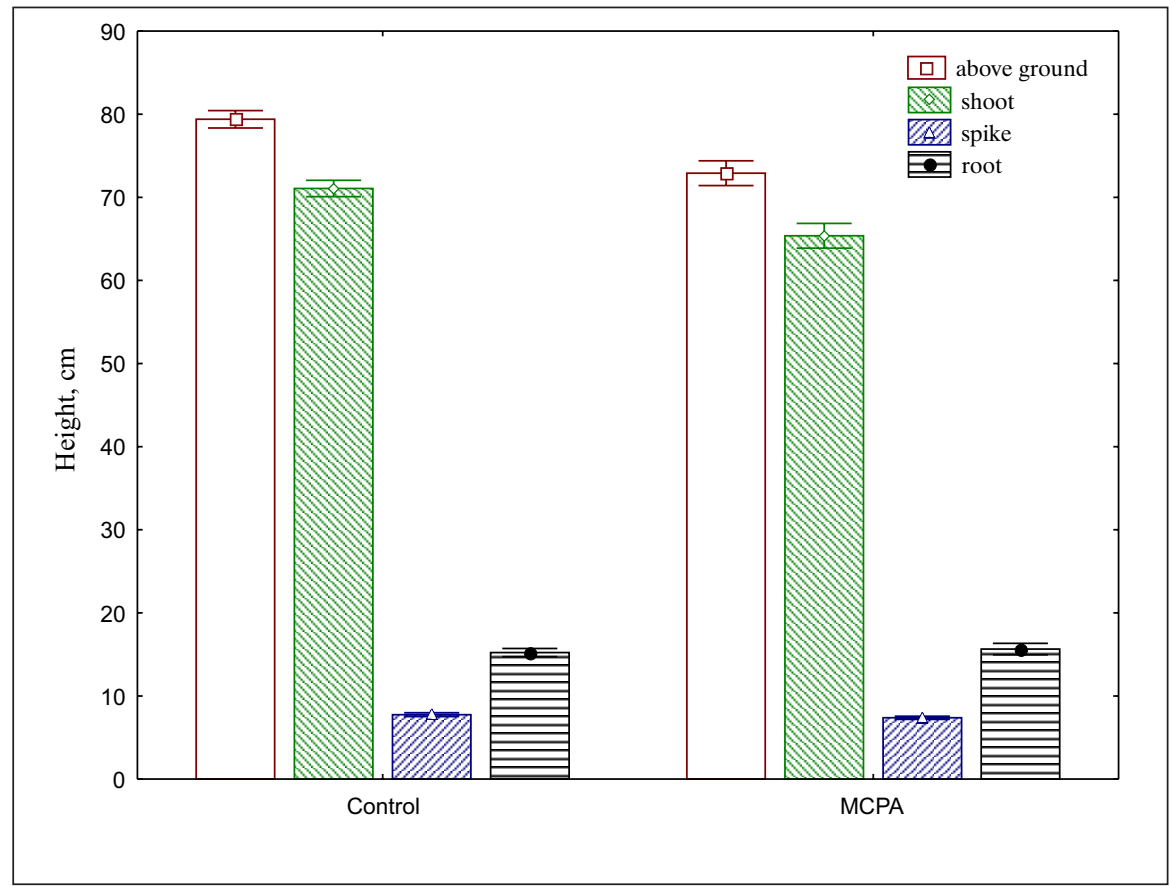

Fig. 1. The height of above-ground part, shoot, spike and root length of spring wheat (Triticum aestivum L.) after MCPA application. Data are mean \pm SE

by $9 \%$ lower than those of control wheat $(\mathrm{F}=10.23 ; \mathrm{p}=0.003)$. The length of spikes and roots was not affected by herbicide $(\mathrm{F}<1.59$, $\mathrm{p}>0.05)$. Reduction of non-target plants growth due to phenoxy herbicides application was proved under laboratory conditions as well. MCPA and 2,4-D reduced the shoot and root growth of T. aestivum and Avena sativa during the 7-day early seedling growth test (Grabińska-Sota et al., 2003). Root length reduction during this study was observed because the plant seeds were directly exposed to herbicides and after the emergence the roots were always in constant herbicide concentration solutions. In our mesocosm study, on the contrary, MCPA was sprayed on the plants and negative impact on roots might by observed only in case of relatively high MCPA concentration on the soil.

The spring wheat sprayed with MCPA reached by $28.57 \%$ lower shoot biomass at the end of the field study compared to control plants ( $\mathrm{p}=0.013$ ) (Fig. 2). However, the difference in dry weight of shoot was smaller $(10.3 \%)$ and statistically insignificant $(\mathrm{p}=0.22)$. A similar tendency in weight decrease was observed during the laboratory studies simulating wheat and maize spraying with herbicides (Nemat Alla et al., 2008; Dragičević et al., 2010). There was no impact of MCPA on the fresh root weight, although the reduction by $17 \%$ in dry root weight was observed. During the study of various herbicides impact via spray and media exposure on non-target species barley (Hordeum vulgare L.) an increased root:shoot (weight and length) ratio in MCPA treated plants was observed (Cedergreen, 2008). The study of MCPA herbicide sensitivity among different non-target crop and wild plant species demonstrated that wheat weight growth is quite insensitive to MCPA in comparison with such species as Lycopersicum esculentum, Lactuca sativa, Glycine max and others (White, Boutin, 2007).

Our results indicate that the growth of spring wheat is not affected when the recommended dose of MCPA is applied. However, slight reduction in shoot and root growth may indicate that in higher doses the impact of MCPA on the non-target plants may be more pronounced.

MCPA effects on the productivity of T. aestivum were estimated as the weight of spikes, 


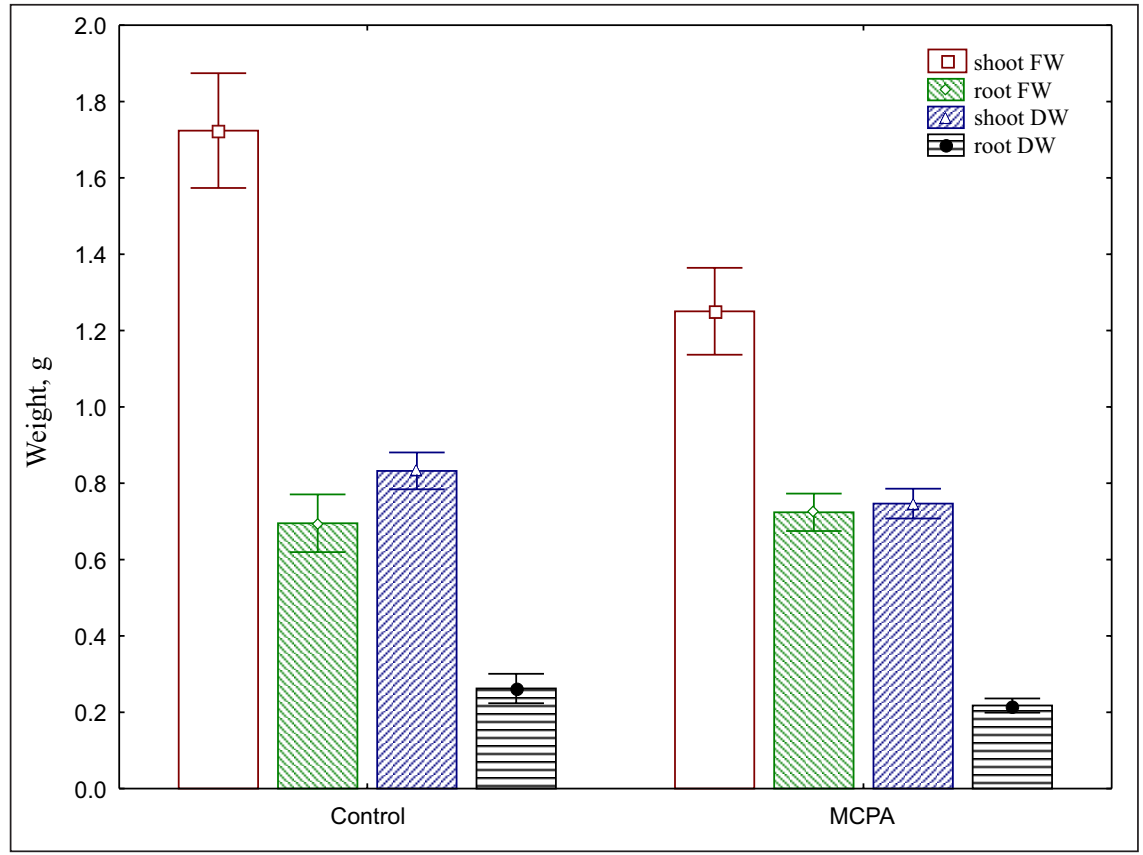

Fig. 2. Spring wheat (Triticum aestivum) fresh and dry weight of shoot and root after MCPA application. Data are mean \pm SE

amount of grains in the spikes and the grain weight. Despite the fact that the length of spikes was slightly reduced after MCPA application (Fig. 1), the weight of spikes was changed in the opposite direction and slight increase (by 4\%) in spike fresh weight was observed (Fig. 3). Moreover, MCPA reduced the content of hulls in the spikes by $11.1 \%$. This indicates that the increase in grain quantity and / or weight occurred. No significant impact on the number of produced grains was observed, but the fresh and dry weight of grain significantly increased $(\mathrm{p}<0.03)$ by $9 \%$ and $11 \%$, respectively, after MCPA application. It indicates that due to reduced competition with the weeds the crops may produce more grains and this may result in higher yield. The increase in yield of wheat grown under field conditions and in greenhouse was recorded after the application of MCPA and in mixture with 2,4-D (Lisova, 2001; Baghestani et al., 2007). Though during the field studies in Cana$\mathrm{da}$, the reduction in wheat yield was observed after the treatment with phenoxy herbicides

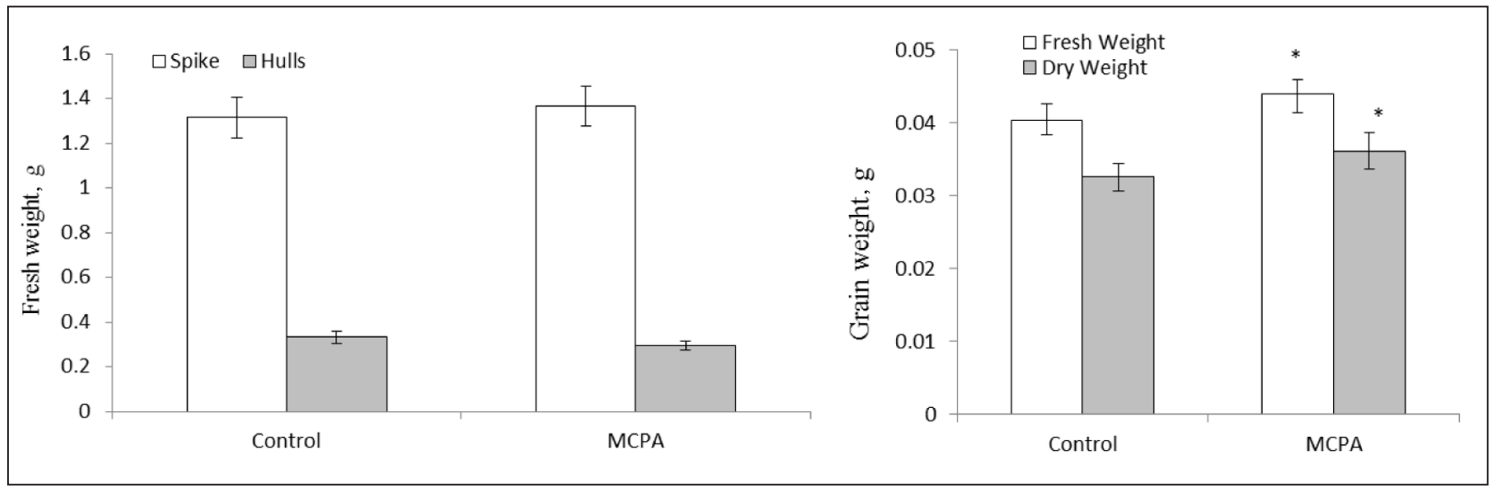

Fig. 3. Fresh weight of T. aestivum spikes and hulls (left) and grain fresh and dry weight (right). Data are mean \pm SE 
(Sikkema et al., 2007) and with mesotrione (Soltani et al., 2011).

MCPA had a slight stimulatory effect on the content of photosynthetic pigments (Fig. 4). The content of chlorophyll $a$ increased by $4.8 \%$, chlorophyll $b$ - by $9.5 \%$ and carotenoids - by $11.5 \%$. However the reduction of chlorophyll content due to plants exposure to various herbicides was reported in numerous studies (Wang, Zhou, 2006; Zaltauskaitè, Brazaitytè, 2013).

Lipid peroxidation is a sensitive measure of oxidative damage and is useful as a biomarker for oxidative stress. MDA content in plants treated with MCPA decreased by $13.94 \%$, though this reduction was not significant $(\mathrm{p}=0.29)$ (Fig. 4). These results show that MCPA do not provoke lipid peroxidation in the tissues of T. aestivum. This phenomenon may be explained by the fact that MCPA is a synthetic auxin and the dose applied might not stimulate reactive oxygen species (ROS) production. The increase in MDA content was recorded in wheat leaves after 1-day exposure to chlorimuron-ethyl and decreased with time (Wang, Zhou, 2006). Lipid peroxidation due to MCPA application has not been studied and we cannot compare our results with those of other studies, however, oxidative stress due to auxin application was recorded (Grossmann et al., 2001).
The residues of MCPA in soil and wheat were analysed (Table). MCPA residues in soil do not exceed the maximum allowable concentration $(0.04 \mathrm{mg} / \mathrm{kg})$ (HN 97:2000). Usually the residues in soil do not exceed $0.05 \mathrm{mg} / \mathrm{kg}$ (Caux et al., 1995). Higher amount of MCPA was accumulated in the shoots $(0.047 \mathrm{mg} / \mathrm{kg})$ and no MCPA residues were detected in the grains. It indicates that grains are safe for use if MCPA is applied under the recommended dose. However, if the doses are exceeded, the study indicates that it may pose the risk for wheat users.

Table. The MCPA concentrations in soil and spring wheat (Triticum aestivum)

\begin{tabular}{cc}
\hline & Concentration $(\mu \mathrm{g} / \mathrm{g})$ \\
\hline Soil & 0.001 \\
\hline Wheat shoots & 0.047 \\
\hline Wheat grains & n. d. \\
\hline
\end{tabular}

n. d. - not detected

\section{CONCLUSIONS}

The study revealed that herbicides cause adverse effects on non-target crop species. The herbicide application slightly reduced the growth and dry weight of T. aestivum. The herbicide did not evoke a significant effect on the content of photosynthetic pigments and did not

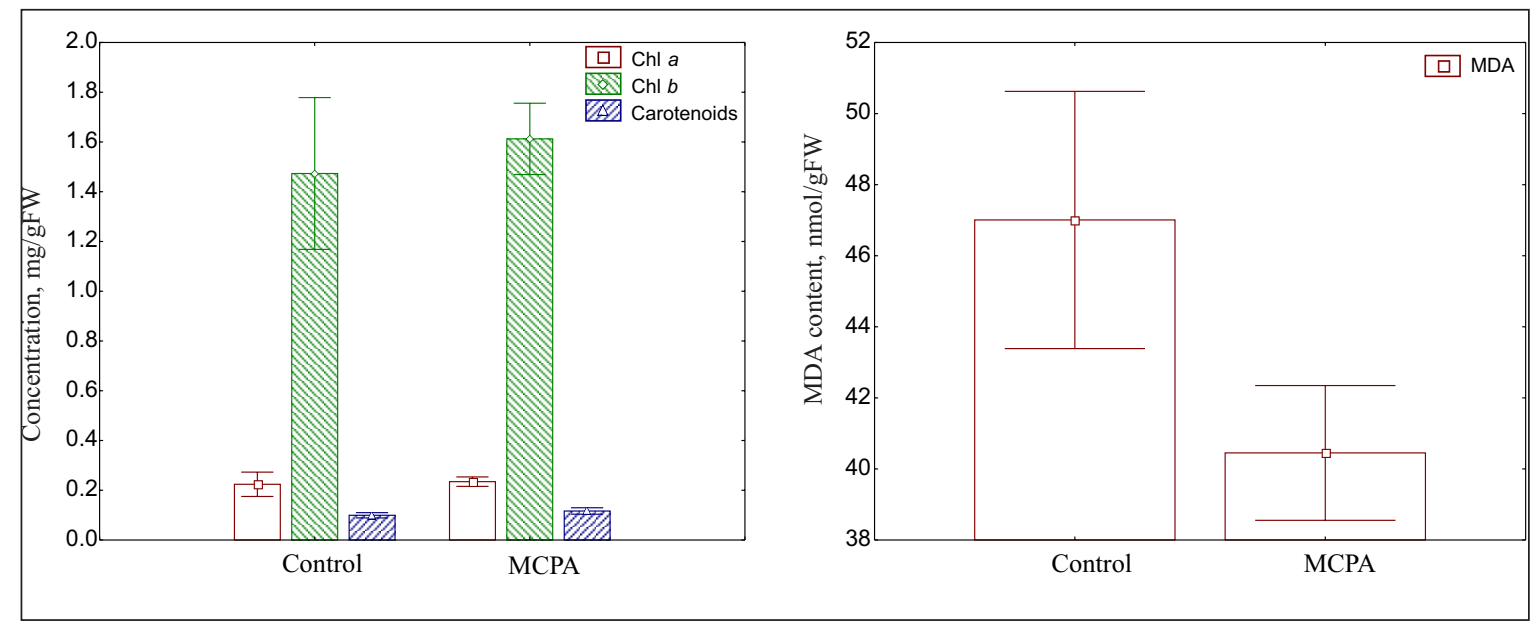

Fig. 4. Concentrations of photosynthetic pigments and MDA in spring wheat (Triticum aestivum) after MCPA application. Data are mean \pm SE 
evoke oxidative stress in plant tissues. Residues of MCPA were found in soil and wheat shoots though they did not exceed the maximum allowable concentrations.

T. aestivum is a monocot and it is likely that MCPA used for control of dicot species in monocot crops should not exhibit high toxicity to $T$. aestivum, however, the study revealed that $T$. aestivum demonstrated low sensitivity to MCPA even under the recommended dose application.

Received 06 June 2014

Accepted 20 August 2014

\section{References}

1. Baghestani MA, Zand E, Soufizadeh S, Mirvakili $\mathrm{M}$, Jaafarzadeh N. Response of winter wheat (Triticum aestivum L.) and weeds to tank mixtures of 2,4-D plus MCPA with clodinafop propargyl. Weed Biol Manag 2007; 7: 209-18.

2. Buege JA, Aust SD. Microsomal lipid peroxidation. Meth Enzym 1978; 52: 302-10.

3. Caux P-Y, Kent RA, Bergemon V, Fan GT, MacDonald DD. Environmental fate and effects of MCPA: a Canadian perspective. Crit Rev Env Sci 1995; 25: 313-76.

4. Cedergreen N. Herbicides can stimulate plant growth. Weed Res 2008; 48: 429-38.

5. Comoretto L, Arfir B, Chiron S. Pesticides in the Rhône river delta (France): basic data for a field-based exposure assessment. Sci Total Env 2007; 380: 124-132.

6. de Snoo GR, van der Poll RJ. 1995. Effect of herbicide drift on adjacent boundary vegetation. Agr Ecosyst Env 1995; 73: 1-6.

7. Dragičević V, Simić $M$, Stefanović L, Sredojević S. Possible toxicity and tolerance patterns towards post-emergence herbicide in maize inbred lines. Fresen Env Bull 2010; 19(8): 1499-04.

8. Fargašová A. Comparative study of plant growth hormone (herbicide) toxicity in va- rious biological subjects. Ecotox Env Safety 1994; 29: 359-64.

9. Fedtke C, Duke SO. Herbicides. In: B. Hock, E.F. Elstner. Plant toxicology, 2005. Marcel Dekker, New York, 648.

10. Grabińska-Sota E, Wiśniowska E, Kalka J. Toxicity of selected synthetic auxines - 2,4-D and MCPA derivatives to broad-leaved and cereal plants. Crop Prot 2003; 22: 355-60.

11. Grossmann K, Kwiatkowski J, Tresch S. Auxin herbicides induce $\mathrm{H}_{2} \mathrm{O}_{2}$ overproduction and tissue damage in cleavers (Galium aparine L.). J Exp Bot 2001; 52: 1811-16.

12. Grossmann K. Mode of action of auxin herbicides: a new ending to a long, drawn out story. Trends Plant Sci 2000; 5: 506-8.

13. Hansen K, Grossmann K. Auxin-induced ethylene triggers abscisic acid biosynthesis and growth inhibition. Plant Physiol 2000; 124: 1437-1448.

14. Hu J, Yang T, Yin S, Cao D. Dissipation and residue of MCPA (4-chloro-2-ethylphenoxyacetate) in wheat and soil. Env Monit Assess 2012; 184: 5017-24.

15. Kende H, Zeevaart JAD. The five "classical" plant hormones. The Plant Cell 1997; 9: 1197-10.

16. Lisova R. Efficiency of pesticides in spring barley sowing. Biologija 2001; 2: 31-3.

17. Marrs RH, Williams CT, Frost AJ, Plant RA. Assessment of the effects of herbicide spray drift on a range of plant species of conservation interest. Env Pollut 1989; 59: 71-86.

18. Nemat Alla MM, Badawi AM, Hassan NM, El-Bastawisy ZM, Badran EG. Effect of metribuzin, butachlor and chlorimuron-ethyl on amino acid and protein formation in wheat and maize seedlings. Pestic Biochem Phys 2008; 90: 8-18.

19. Sikkema PH, Brown L, Shropshire C, Soltani N. Responses of three types of winter wheat (Triticum aestivum L.) to spring-applied post-emergence herbicides. Crop Prot 2007; 26: 715-20.

20. Soltani N, Shropshire C, Sikkema PH. Response of spring planted barley (Hordeum 
vulgare L.), oats (Avena sativa L.) and wheat (Triticum aestivum L.) to mesotrione. Crop Prot 2011; 30: 849-53.

21. Von Wettstein D. Chlorophyll-lethale und der submik roskopische Formwechsel der Plastiden. Exptl Cell Res 1957; 12: 427-506.

22. Wang M, Zhou Q. Effects of herbicide chlorimuron-ethyl on physiological mechanisms in wheat (Triticum aestivum). Ecotox Envir Safety 2006; 64: 190-97.

23. White AL, Boutin C. Herbicidal effects on nontarget vegetation: investigating the limitations of current pesticide registration guidelines. Envir Toxic Chem 2007; 26: 2634-43.

24. Žaltauskaitė J, Brazaitytè V. Assessment of the effects of sulfonylureas herbicide amidosulfuron application on target and non-target organisms. Fresen Envir Bull 2013; 22, 7a: 1977-82.
Jūratė Žaltauskaitè, Giedrẻ Kišonaitė

FENOKSI HERBICIDE MCPA POVEIKIS NE-

TAIKINEI AUGALIJAI VASARINIŲ KVIEČIŲ (TRITICUM AESTIVUM L.) PASĖLIUOSE

\section{Santrauka}

Lauko tyrimų metu ịvertintas fenoksi herbicido MCPA (4-chlor-2-metil-fenoksi rūgštis) poveikis morfologinèms ir fiziologinèms netaikinio augalo vasarinio kviečio (Triticum aestivum L.) charakteristikoms. Eksperimentas vykdytas 2012 m. gegužèsrugpjūčio mèn. 4 mezokosmo ploteliuose $(0,1 \mathrm{a})$. Augalai buvo purkšti herbicidų tirpalais pagal rekomenduojamą naudoti normą. Tirti rodikliai: stiebų aukštis, šaknų ilgis, sausa biomase, chlorofilo $a$ ir b, karotenoidu ir malondialhehido (MDA) koncentracija, derlingumas, MCPA likučiai kviečiuose ir dirvožemyje. Nustatyta, kad herbicidas šiek tiek sumažino kviečių aukštį $(9 \%, \mathrm{p}<0,05)$, pailgino šaknų ilgi ( $p>0,05)$. Sausa stiebų ir šaknų masė sumažèjo atitinkamai $14 \%(\mathrm{p}<0,05)$ ir $17 \%(\mathrm{p}>0,05)$. Herbicidas nesukèlè reikšmingo fotosintezès pigmentų ir MDA koncentracijos pokyčių. MCPA likučiai buvo nustatyti tik dirvožemyje ir kviečių stiebuose (atitinkamai 0,97 $\mu \mathrm{g} / \mathrm{kg}$ ir 0,047 mg/kg).

Raktažodžiai: herbicidai, netaikiniai augalai, oksidacinis stresas, fitotoksiškumas, Triticum aestivum 